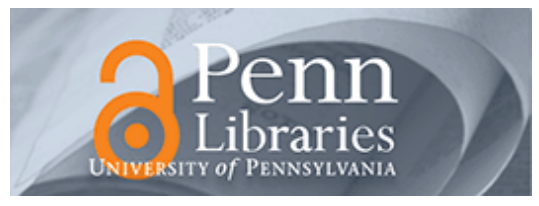

University of Pennsylvania

ScholarlyCommons

9-2002

\title{
Retaining African Americans in Higher Education: Challenging Paradigms for Retaining Students, Faculty, and Administrators (Review)
}

\section{Laura W. Perna}

University of Pennsylvania, Iperna@gse.upenn.edu

Follow this and additional works at: https://repository.upenn.edu/gse_pubs

Part of the Educational Assessment, Evaluation, and Research Commons, Educational Sociology Commons, Higher Education Commons, Higher Education Administration Commons, and the Race and Ethnicity Commons

\section{Recommended Citation}

Perna, L. W. (2002). Retaining African Americans in Higher Education: Challenging Paradigms for Retaining Students, Faculty, and Administrators (Review). The Journal of Higher Education, 73 (5), 652-659. http://dx.doi.org/10.1353/jhe.2002.0049 


\title{
Retaining African Americans in Higher Education: Challenging Paradigms for Retaining Students, Faculty, and Administrators (Review)
}

\author{
Abstract \\ Retaining African Americans in Higher Education is a timely and novel approach to a critical topic. Edited \\ by Lee Jones, associate dean for academic affairs and instruction in the College of Education and \\ associate professor in Educational Leadership at Florida State University, the volume contains 14 \\ chapters, a preface, a conclusion, and two personal reflections that describe issues related to the \\ retention of African American students, administrators, and faculty at predominantly white colleges and \\ universities. "Written about African Americans, by African Americans" (p. xii), this book is recommended \\ by a white woman for higher education administrators, faculty, researchers, and policymakers of all racial \\ and ethnic groups.

\section{Disciplines} \\ Education | Educational Assessment, Evaluation, and Research | Educational Sociology | Higher Education \\ | Higher Education Administration | Race and Ethnicity
}


Retaining African Americans in Higher Education:

Challenging Paradigms for Retaining Students, Faculty, and Administrators, edited by Lee Jones. Sterling, VA:

Stylus, 2001. 288 pp. \$59.95 (\$24.95)

LAURA W. PERNA, University of Maryland

Retaining African Americans in Higher Education is a timely and novel approach to a critical topic. Edited by Lee Jones, associate dean for academic affairs and instruction in the College of Education and associate professor in Educational Leadership at Florida State University, the volume contains 14 chapters, a preface, a conclusion, and two personal reflections that describe issues related to the retention of African American students, administrators, and faculty at predominantly white colleges and universities. "Written about African Americans, by African Americans" (p. xii), this book is recommended by a white woman for higher education administrators, faculty, researchers, and policymakers of all racial and ethnic groups.

The perspectives included in this volume offer insights that may be particularly helpful for guiding practice and research in this post-affirmative action era. The recent legal and political attacks on affirmative action in college admissions, most notably Proposition 209 in California and Hopwood vs. Texas (1996), provide one stimulus for rethinking traditional approaches to the retention of African Americans. Although discussions of the legal issues pertaining to affirmative action are quickly dated, given continuing developments in this area, Eugene L. Anderson, doctoral candidate in the Department of Educational Policy Studies at the University of Virginia, provides a succinct review of the legal history through July 2000.

Original thinking on this topic is also needed because, despite numerous suggestions for closing the gap, retention in higher education continues to be lower for African Americans than for whites. Those who care about the retention of African Americans in higher education need to carefully consider the most appropriate ways to communicate this persisting problem. One of the primary weaknesses of this volume is that the continued underrepresentation of African Americans among

Laura W. Perna is assistant professor, Department of Education Policy \& Leadership, University of Maryland.

The Journal of Higher Education, Vol. 73, No. 5 (September/October 2002)

Copyright $\odot 2002$ by The Ohio State University 
students, administrators, and faculty is not well documented. Although Anderson and other authors, including Jason DeSousa, vice president for student affairs at Savannah State University, provide useful contextual descriptions of the legal and political issues limiting the retention of African Americans, and others (e.g., Branch; DeSousa) mention the educational benefits of diversity, the volume lacks a clear description of the extent to which the retention of African Americans in higher education is a problem that warrants the allocation of scarce time, money, and other resources. Some of the authors do provide some data on the representation of African Americans among students, administrators, and faculty, but the presentation is often limited in several ways. Specifically, some of the data are dated, while other data are difficult to interpret, given the absence of a reference point (e.g., the representation of African Americans in the population). Although trend analyses can be a useful tool, many of the trends included in this book are limited by focusing on changes over only a one- or two-year period, describing changes for all minorities aggregated together, or failing to acknowledge possible reasons underlying the observed differences across groups (e.g., differential rates of growth in the population of different racial and ethnic groups). Among the best sources of data, some of which are cited but not fully utilized by authors in the volume, are the American Council on Education's Annual Status Report on the Status of Minorities in Higher Education (Wilds, 2000), the Frederick D. Patterson's African American Education Data Book (Nettles \& Perna, 1997), and the National Center for Educational Statistics (2001) Digest of Education Statistics.

Despite this limitation, the book makes several important contributions to our understanding of the issues related to the retention of African Americans in higher education. Although the title implies a narrow focus on "retention," most of the 16 authors appropriately recognize that retention is a process that involves transitions between different positions and statuses. Noting that retaining African American students first requires enrollment, Anderson provides a clear description of such alternative approaches to affirmative action in the college admissions process as the x-percent plans in California, Florida, and Texas and speculates about the effects of these plans on the racial/ethnic diversity of student enrollments at institutions within each state. Paul E. Green, assistant professor of Urban Politics, Policy, and the Law at the University of California, calls for greater attention to the institutional and structural barriers that have limited college access including segregation into lower quality elementary and secondary schools, increased emphasis on standardized test scores in the college admissions process, changes in federal financial aid, and growth in college tuition. With 
regard to administrators, J. W. Wiley, director of the Center for Diversity, Pluralism, and Inclusion at the State University of New York-Plattsburgh and adjunct professor of philosophy, notes the importance of the recruitment process and encourages African Americans to ask questions regarding support staff, "budget realities," office location, equipment, support for personal development, travel opportunities, and the management style of superiors prior to accepting an administrative position, arguing that the answers to these questions may signal the probability of subsequent job success and satisfaction. André J. Branch, assistant professor in the School of Teacher Education at San Diego State University, argues that retaining African American faculty is contingent, in part, on the successful recruitment and retention of African American graduate students, asserting that African American graduate students provide African American faculty with a likely source of research assistance, affirm the work of African American faculty, and enable African American faculty to realize the satisfaction associated with mentoring African American graduate students. Offering a basic description of the levels of review during the tenure process, Lemuel W. Watson, associate professor of higher education, claims that African Americans should be mentored about tenure requirements during graduate school and that planning for tenure and promotion processes should begin when the doctorate is received.

Another strength of this work is that, consistent with Jones' stated goals, most authors conclude their essays with practical recommendations for improving the retention of African Americans. Taken together, these recommendations offer a comprehensive assessment of the issues influencing the retention of African American students, faculty, and administrators. With regard to students, Jones suggests strategies for fostering an inclusive climate, providing academic and social support, and helping students to obtain adequate financial aid. Among other recommendations, James L. Moore III, assistant professor in counselor education at the University of South Carolina, encourages parents and families to set high educational expectations for their child, continuously support and encourage their child while enrolled in college, and become involved in their child's college experiences. He also recommends that administrators and faculty work to involve parents and families in retention and other academic programs. In one of the few chapters describing original empirical research, Jerlando F. L. Jackson, visiting assistant professor of higher and postsecondary education at the University of Wisconsin at Madison, proposes various strategies for increasing the retention of African American administrators at predominantly white colleges and universities, such as ensuring equity in wages and salaries, of- 
fering an orientation program to the institution and community, developing a mentoring program, encouraging constructive feedback, and promoting professional and career development. Stressing the value of establishing a community of social support, Raphael M. Guillory, doctoral student in higher education administration at Washington State University, offers such strategies to African American administrators as developing expertise beyond the minimum job requirements, forming coalitions with key individuals within the institution, and enhancing credibility by earning advanced degrees. Branch suggests that improving the retention of African American faculty requires achieving a critical mass of African American faculty, providing institutional support through orientation, mentoring, protection of workload and support for an African American research agenda, and aggressively recruiting African American graduate students. Watson recommends that African American faculty should develop a plan for achieving tenure, learn to reject assignments that are not consistent with that plan, and take advantage of opportunities to socialize with faculty colleagues.

While the suggested strategies provide a useful starting point for those who are interested in working to improve the retention of African Americans, the authors generally present little evidence demonstrating the effectiveness of the proposed strategies. Therefore, the recommended strategies should not only be offered for consideration to practitioners but also be used to guide future research on the retention of African American students, administrators, and faculty. More research is required to systematically examine the effects of the recommended strategies in general, as well as variations in the effects across different groups (e.g., African American men and women, undergraduate and graduate students) and at different types of institutions (e.g., historically black and predominantly white institutions, research universities, and community colleges), differences that, although alluded to by some authors, are generally not addressed.

This volume raises other important issues for those who are interested in improving the retention of African Americans at our nation's higher education institutions. One issue is the extent to which retention strategies should focus broadly on students, administrators, and faculty regardless of race or ethnicity or should target African Americans specifically. Some authors (e.g., Jones, Jackson) note that many factors that influence institutional access and success for African Americans also apply to individuals of other racial and ethnic groups. Others (e.g., Branch) speculate that, while some challenges may not be experienced exclusively by African Americans, barriers to retention are generally greater for African Americans than for whites. Most authors note that 
many African Americans must also cope with such obstacles as racism, hostility, prejudice, discrimination, "chilly" climate, institutional bias, negative stereotypes, self-doubt, alienation, isolation, cultural insensitivity, and glass-ceiling effects. Additionally, African American administrators and faculty must also contend with heavier workloads resulting from demands to mentor African American students and faculty and serve on greater numbers of committees. The general failure of traditional approaches to increasing the retention of African American students, administrators, and faculty strongly suggests that it is time to move beyond strategies that focus on the characteristics of African Americans toward strategies that improve the institutional climate of predominantly white institutions for African Americans.

A related but more controversial issue pertains to the centrality of race in the research conducted by African American faculty. One way in which Jones successfully achieves his stated goal "to open dialogue by challenging traditional paradigms for retaining African American students, administrators, and faculty at predominantly white colleges and universities" (p. xi) is by including various viewpoints on this issue. For example, while acknowledging the need to bring new perspectives to teaching, research, and administration in higher education institutions, Watson asserts that African American faculty need to "conduct research that is respected by peers" (p. 242) in order to achieve tenure and promotion. In contrast, while noting that African American faculty may be reluctant to engage in research that incorporates black agency or black voice in part because of a perception that such research is devalued, Derrick P. Aldridge, assistant professor in the Department of Social Foundations of Education at the University of Georgia, contends that African American faculty need "to redefine and refine the study of black people, take a lead in the methodological and theoretical construction of such research, and let their voices and experiences as black people be heard in their research" (p. 196). In a creative essay that uses Bebop as a vehicle for describing the challenges faced by African American scholars, Shuaib Meachan, assistant professor of literacy instruction in the School of Education at the University of Delaware, argues that African American researchers should define their intellectual purpose, mission, and legacy, strive to incorporate a variety of interpretations and ideas, and, while recognizing that academic rewards emphasize individual accomplishment, also establish intellectual and social connections with the African American community. Drawing on the work of W. E. B. DeBois, Leon D. Caldwell, assistant professor of educational psychology at the University of Nebraska at Lincoln, and James B. Stewart, professor of labor studies and industrial relations and African and African-American 
Studies at Pennsylvania State University, argue that retention requires African American faculty to progress through a developmental process of "psychic liberation," moving from a focus on satisfying promotion and tenure requirements and being minimally involved with the African American community to reevaluating institutional allegiances and priorities, to becoming much more involved in African American professional and cultural activities, and to mentoring to produce other "liberated" African Americans. Adopting retention strategies that focus on improving the institutional climate, in general, and foster a more supportive environment for African Americans, in particular, is likely to minimize the extent to which the centrality of race in the research of African American faculty is an issue.

Some readers will be disappointed that this book does not include a chapter that directly builds on one of the book's greatest strengths, namely viewing the retention of African Americans as a topic that pertains not only to students and faculty, but also to administrators-a group for which very little empirical research has been conducted. Jones concludes the volume with a "five-year multicultural student retention plan," a plan that includes virtually no attention to issues related to the retention of African American administrators and faculty. Although some readers will find his clear statement of goals and strategies, as well as his outline of a reorganized office of multicultural student services, to be helpful, others will be frustrated that the only reference in the plan to faculty or administrators is to increase the number of faculty of color. This is certainly a worthwhile goal, given Branch's claims that increasing the number of African American faculty will strengthen the support available for African American students and that achieving a critical mass of African American faculty will improve the retention of African American faculty. Nonetheless, the recommended plan fails to incorporate other suggestions in the volume. For example, as observed by Branch and Watson, increasing the retention of faculty of color is a complex process that requires attention to such issues as mentoring during graduate school and as new faculty, protecting workloads, and achieving tenure. Attention to the retention of African American administrators would seem to be a vital component of any comprehensive institutional retention plan, given Jackson's assertion that the racial diversity of an institution's administrators provides a signal to students of the institution's commitment to diversity, Guillory's claim that administrators are the true source of power within an institution, and Wiley's contention that the issues related to the retention of African American administrators are not necessarily the same as the issues related to the retention of African American students and faculty. 
The most critical issue arising from a review of the essays in this volume is the extent to which we, as higher education professionals, not only acknowledge that there is a "crisis" in American higher education with regard to the status of African Americans, as Green argues, as well as with regard to the identity, purpose, and impact of African Americans, as Meacham argues, but also are committed to acting to create and maintain colleges and universities that are racially and ethnically diverse at all levels - student, administration, and faculty. Summarizing research showing that African American faculty perceive a lack of support, discrimination, and isolation as well as research showing institutional resistance to efforts to recruit and retain African American faculty, Branch concludes that trustees, administrators, and faculty at our nation's predominantly white higher education institutions may not want to recruit and retain African American faculty. The continued underrepresentation of African Americans among students, administrators, and faculty strongly suggests the need to move beyond approaches that focus on the characteristics of African Americans to strategies that address the underlying issue, namely an institutional climate that is often characterized by racism, prejudice, and discrimination.

Jones and colleagues strongly encourage us to act to improve the retention of African Americans. Those who are interested in responding to the authors' call to improve the campus climate may find it helpful to build on the useful description of relevant issues provided by Jones and colleagues by referring to the emerging body of research on this topic. Recent research not only documents the negative effects of prejudice and discrimination on retention and other college-outcomes for African Americans as well as for whites (e.g., Cabrera, Nora, Terenzini, Pascarella, \& Hagedorn, 1999) but also offers a framework for understanding and improving the campus climate. Observing that "probably no area of campus life has been so devoid of policy initiatives as the racial climate at individual institutions" (p. 279), Hurtado, Milem, ClaytonPederson, and Allen (1998) proposed a framework that focuses on four interrelated aspects of the institutional context: the historical legacy regarding racial/ethnic integration, structural diversity or the representation of individuals of color on campus, the psychological climate or perceptions of group relations and racial discrimination, and behavioral aspects including interactions across racial/ethnic groups.

Clearly words that acknowledge the existence of an unsupportive climate must be accompanied by actions that reflect a commitment to equal educational opportunity at all levels of an institution and that produce an institutional academic and social climate that is inclusive, embracing the diversity of cultural norms, values, and perspectives. Al- 
though creating an institutional climate where all African Americans can, in Branch's words, be "full contributing, power-sharing members" is obviously not easily or quickly achieved, this book provides a useful starting point to guide both practice and research on this critical issuethe retention of African American students, faculty, and administrators at our nation's predominantly white colleges and universities.

\section{References}

Cabrera, A. F., Nora, A., Terenzini, P. T., Pascarella, E., \& Hagedorn, L. S. (1999). Campus racial climate and the adjustment of students to college: A comparison between white students and African American students. Journal of Higher Education, 70, $134-160$.

Hurtado, S., Milem, J. F., Clayton-Pedersen, A. R., \& Allen, W. R. (1998). Enhancing campus climates for racial/ethnic diversity: Educational policy and practice. Review of Higher Education, 21, 279-302.

Nettles, M. T., \& Perna, L. W. (1997). African American education data book, Volume I: Higher and adult education. Fairfax, VA: Frederick D. Patterson Research Institute.

National Center for Education Statistics. (2001). Digest of education statistics. Washington, DC: U. S. Department of Education. (NCES 2001-034)

Wilds, D. J. (2000). Seventeenth annual status report on minorities in higher education. Washington, DC: American Council on Education. 